\title{
BOTRYOSPHAERIA TREE FUNGAL PATHOGENS AND THEIR DIVERSITY
}

\author{
aWendu A. Darge, bSamuel S. Woldemariam \\ ${ }^{a}$ Centeral Ethiopia Environment and Forest Research Center, Ethiopia. \\ ${ }^{b}$ Faculty of Natural and Computational Science, University of Gondar, Gondar, Ethiopia.
}

\section{A R T I C L E I N F O}

\section{Article History}

Received: December 08, 2020

Revised: January 31, 2021

Accepted: March 27, 2021

\section{Keywords}

Botryosphaeria dothidea

Ascomycetes

Eucalyptus plant spp.

Stress

\section{A B S T R A C T}

The genus Botryosphaeria identified in 1863 as saprophytes of dead tissue of woody plants have been described as pathogens of economically important plantation trees in agriculture and native forests. The genus is a species-rich, worldwide distributed occurring on diverse host ranges. Species of the Botryosphaeria are reported as the pathogens of many plantation trees, including species of Acacia, Eucalyptus, and Pinus causing canker and rapid dieback diseases which often end up in death. Botryosphaeria fungal pathogens have cross pathogenicity on different host tree species which enables them important and focus area of research. The taxonomy of Botryosphaeria spp. have been under research, identification of these fungi has generally been based on morphological features of the anamorph that usually seen under the microscope. Characters that are used to classify genera in the Botryosphaeria have mostly relied on the macroscopic features of the ascospores and the conidial features. Currently, molecular techniques such as DNA sequencing involving amplification of ITS region are important for exact identification of the genera to species level. Recent molecular, phylogenetic and morphological findings showed that order Botryosphaeriales is diverse consisting nine families and 33 genera with 23 genera only in the family Botryosphaeriaceae. Botryosphaeria spp. are naturally endophytes associated with tree plants known to cause monocyclic or polycyclic diseases resulting in polyetic epidemics. The factor that makes plants more prone to Botryosphaeria fungal species is assumed to be stress or wounding associated with the host plants. Global climate change driven drought is an important factor that initiate stress resulting in nutrient deficiencies. Botryosphaeria fungal tree diseases can be best managed by ensuring plants are in optimal health through appropriate integration of cultural, silvicultural and fungicidal applications to effectively prevent and control the diseases.

Corresponding Author: Wendu A. Darge

Email:wendu70@gmail.com

(C) The Author(s) 2021.

\section{INTRODUCTION}

The genus Botryosphaeria since identified, as saprophytes of dead tissue of woody plants in 1863, repeatedly reported as pathogens, particularly within the nursery and economically important trees utilized in agriculture and forestry (Slippers and Wingfield, 2007). The genus is reported diverse, occurring on a various host starting from monocotyledonous, dicotyledonous, and gymnosperm hosts to woody branches, herbaceous leaves, stems and haulms of grasses, twigs to the thalli of lichens as saprobic, parasitic and endophytic nature usually causing die-back and canker diseases (Crous et al., 2006; Pavlic et al., 2007).

Botryosphaeria fungi were reported as opportunistic pathogens existing symptomless hidden in plant tissues with potential of pathogenicity when plants are under 
stressing environmental situations like drought, freezing, hot or cold winds, hail wounds or damage which expose to insects pests or other pathogens (Anderson et al., 2004; Slippers and Wingfield, 2007; Gonthier and Nicolotti, 2013; Moral et al., 2019). Research reports reveals that Botryosphaeria species are pathogens of many plantation trees, like Acacia, Eucalyptus and Pinus (Mohali et al., 2009). Gezahgne et al. (2004) also reported that Botryosphaeria species were among the fungi that cause the most damaging canker and dieback disease of Eucalyptus spp. in Ethiopia. Jami et al. (2014) showed that diverse ecological range and cryptic endophytic property leads these fungi prime for being spread with living material and infect both native and non-native trees. Recent research findings revealed that the species within the genus are now causing new disease outbreaks within the world (Phillips et al., 2013).

Several research findings also indicates increasing evidence of identified new species of the Botryosphaeriaceae related to global climate change (Desprez-Loustau et al., 2006; Slippers and Wingfield, 2007; Phillips, 2016). The increasing importance of Botryosphaeria due to pressure on plant communities as a result of climate change is a key motivation to focus on and compile existing knowledge about host, symptoms, taxonomy, diversity, distribution, pathogenicity and management options of this group of fungi for better widen awareness and future ease of identification, prevention and control of associated diseases.

\section{TAXONOMY OF BOTRYOSPHAERIA TREE FUNGAL PATHOGENS}

The family of Botryosphaeriaceae was reported being passed through sere of taxonomic revisions over the past years and now referred to as large family of filamentous fungi within the Ascomycota of which first members were described in the 1820s as species of Sphaeria (Phillips et al., 2013; Slippers et al., 2013).The genus Botryosphaeria was reported by Cesati and De Notaris in 1863 and Theissen and Sydow grouped the family Botryosphaeriaceae and therefore the genus Botryosphaeria as sub-class of the Dothideinae in 1918 (Slippers et al., 2009; Slippers et al., 2017). Taxonomy of Botryosphaeriaceae and Botryosphaeria are under several revisions to different family and subfamily up to now, but Schoch et al. (2006) introduced the order Botryosphaeriales, containing single family, Botryosphaeriaceae and genera Botryosphaeria using multigene based phylogeny for the first time.

\section{IDENTIFICATION OF BOTRYOSPHAERIA SPECIES Identification of Botryosphaeria spp. using morphological method}

Botryosphaeria spp.are often easily distinguished from the remainder of fungal groups by their macroscopic features like grey to black aerial mycelium and gray to indigo or grey to black pigment visible from the reverse side of cultures on the petri plates (Crous et al., 2006; Phillips et al., 2008). Asexual morphs are reported to be easily observed on cultures induced in Water Agar (WA), or pine needles and regularly used for identification because of minor differences across the taxon (Figure 1) while, sexual morphs have little taxonomic importance due to their variation in response to different substrate or growth conditions (Phillips et al., 2013). In recent years, identification of genus Botryosphaeria to species level is accurately done in combination of DNA sequence data with the morphological characteristics (Denman et al., 2003; Phillips et al., 2008).

\section{Identification of Botryosphaeria species using molecular methods}

In recent years, molecular techniques involving analysis of internally transcribed spacer (ITS) of the ribosomal RNA gene region (rRNA) is quicker and accurate identification method to differentiate between closely related Botryosphaeria species of overlapping features than traditional morphological methods (Phillips, 2002; Slippers et al., 2017). DNA sequence analysis of the ITS region are often more accurate and informative if it involves other explanatory gene regions: introns of protein-encoding genes, $\beta$-tubulin, actin, EF1- $\alpha$ and the RNA polymerase II (rpb2) to differentiate among very closely related genera to species of Botryosphaeria like $B$. dothidea and Neofusicoccum parvum (Phillips et al., 2013; Slippers et al., 2017). The minimal DNA sequence of the ITS region required for the identification of Botryosphaeria species is to be 200 base pairs (bp) sequence as reported by Vilas-Boas et al. (2007). 

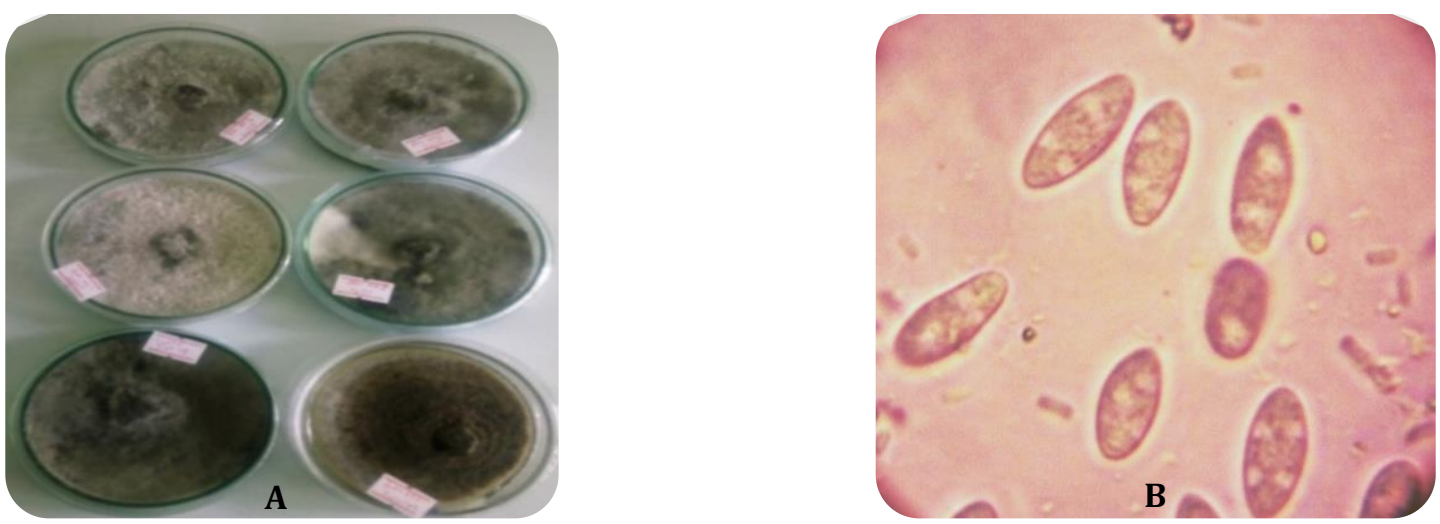

Figure 1. Macroscopic (A) and microscopic (B) morphology of Botryosphaeria specie (Neofusicoccum parvum) from Eucalyptus plants on Malt Extract Agar in Ethiopia (CEE-FRC, 2017).

\section{GENUS AND SPECIES OF BOTRYOSPHAERIA SPECIES DESCRIBED SO FAR}

Currently the taxonomy of Botryosphaeria is reported under Fungi, Phylum Ascomycota, Class Dothideomycetes, order Botryosphaeriales, family Botryosphaeriaceae and genus Botryosphaeria (Denman et al., 2003; Crous et al., 2006; Yang et al., 2017). Recent molecular, phylogenetic and morphological findings revealed that order Botryosphaeriales generally consists 9 families and 33 genera of which 23 genera are within the family Botryosphaeriaceae and genus Botryosphaeria now encompassing, B. agaves, B. corticis, B. dothidea, $B$. fabicerciana, B. fusispora, B. ramose, B. eucalyptorum and B. scharifii (Ahumada, 2005; Abdollahzadeh et al., 2013; Phillips et al., 2013; Slippers et al., 2013).

\section{BIOLOGY OF BOTRYOSPHAERIA TREE FUNGAL PATHOGENS}

Botryosphaeria species were reported to survive frequently on bark and other parts like evergreen leaves as endophytes, latent or opportunists and overwinter as fruiting bodies on dead tissue, germinate epiphytically, penetrate and grow intercellularly and transmitted horizontally in plant tissues (Slippers et al., 2009). Gonthier and Nicolotti (2013) reported Botryosphaeria fungi penetrate the trees using powerful enzymes actively or via the stomata, natural openings, wounds passively and absorb nutrients by producing an appressorium-like hyphal masses.

\section{REPRODUCTION IN BOTRYOSPHAERIA SPP.} Reproduction in Botryosphaeria fungal species

Botryosphaeria spp. have clear sexual (teleomorph) and asexual (anamorph) stages that produce mass of spores from a central ostiole within the pycnidium or perithecium (Phillips et al., 2013). The sexual morphs are not intrinsically important for identification and classification since it varies within a species in several growth conditions (Phillips et al., 2013).Characters aid to differentiate between genera and species of Botryosphaeria have largely relied on the morphological features of the anamorph like conidial shapes, pigmentation, wall thickness, and septation (Phillips et al., 2013). Conidia of the Botryosphaeria are often distinguished by thin-walled, narrow and fusicoccum-like, and thick-walled, wider, diplodia-like conidia (Moral et al., 2019).

\section{EPIDEMIOLOGY, LIFE CYCLE, PATHOGENICITY, AND SYMPTOMS OF BOTRYOSPHAERIA TREE DISEASES}

Species of the Botryosphaeria survive adverse environmental conditions as pycnidia (small dark 'pimple-like' structure) often endophytically, on infected and/or pruned wood and barks while (Phillips et al., 2013; Slippers et al., 2013). The virulent nature of the fungi typically occurs when trees are subjected to stress (Jami et al., 2014). Mechanism of spread for Botryosphaeria species from one plant species to another different is by conidia or ascospores dispersed via wind and rain splashes (Gonthier and Nicolotti, 2013). Botryosphaeria spp. use appressorium, enzymes and toxins for active mechanical penetration and directly through natural openings like stomata and lenticels for colonization of host tissues (ManceroCastillo et al., 2018). After active mechanical penetration fungal mycelium continually grow, advancing after arrival and rupture the leaf epidermis while in the case of wounds, openings like stomata and lenticels, the cell 
walls of xylem vessels and tracheids adjacent to the injuries are extensively lignified becoming necrotic ending up in canker development (Gonthier and Nicolotti, 2013; Moral et al., 2019).

\section{DISEASES AND SYMPTOMS}

Botryosphaeria being opportunistic pathogens trigger several pre-infection processes like adhesion, spore germination, and host recognition once land on susceptible tissues of as pycnidiospores or ascospores, (Slippers et al., 2009; Sammonds et al., 2015).

Symptoms of the disease are usually die-back and canker on twigs, branches and trunks of trees, and more rarely cause diseases like seed-capsule abortion, leaf diseases, seedling diseases and root cankers, blight of shoots, gummosis, in severe cases (Pillay et al., 2013).

\section{HOST RANGES DISTRIBUTION AND CROSS PATHOGENICITY}

Botryosphaeria fungal species exists across all geographical and climatic areas of the planet, except the Polar Regions (Abdella, 2004; Slippers and Wingfield, 2007; Taylor et al., 2009). The fungal species are frequently introduced to new area via imported infected planting or nursery material and jump hosts to cause devastating diseases on native plant species (Slippers et al., 2005). Botryosphaeria spp. are reported to cause diseases on important forest tree species worldwide particularly on Acacia spp., Pinus spp., Olea spp., Prunus spp., Syzygium species and Eucalyptus spp. (Abdollahzadeh et al., 2013). Pavlic et al. (2007), Pillay et al. (2013), and Jami et al. (2014) reported the cross pathogenicity of Botryosphaeria spp.specially Botryosphaeria dothidea, among Syzygium, Eucalyptus spp. and Acacia spp. (Figure 2).

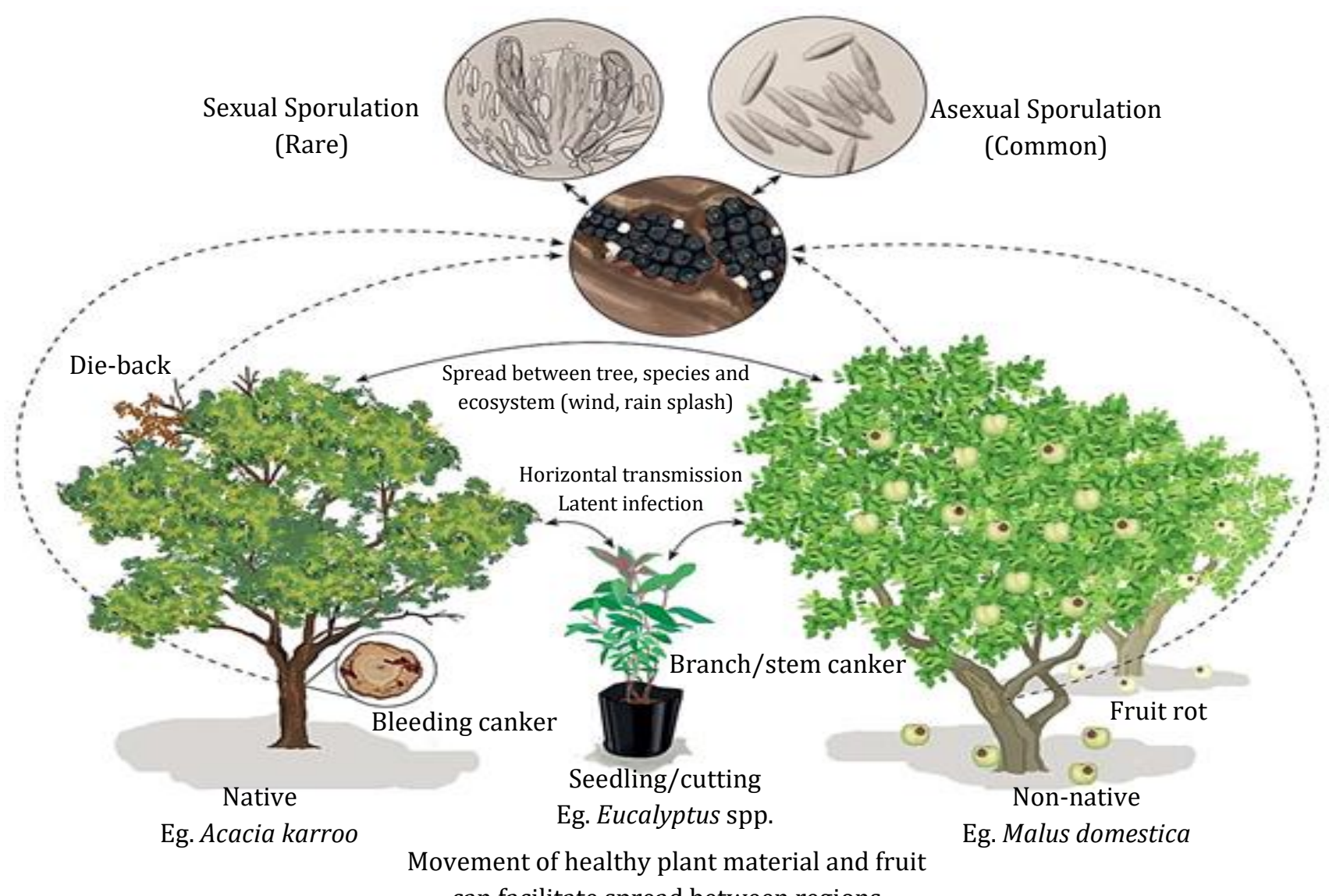

can facilitate spread between regions

Figure 2. An illustrative example of typical disease symptoms, host associations, sporulation and cross pathogenicity of Botryosphaeria dothidea fungus on three hosts, including native (Acacia sp.) and non-native (Eucalyptus and Malus spp.) hosts (Marsberg et al., 2016). 
FACTORS CONTRIBUTING TO DISEASES INITIATION AND SYMPTOM DEVELOPMENTS

Botryosphaeria spp. penetrate trees through wounds from mechanical damage or natural openings (Jami et al., 2014). Insects, animals, hail, windstorms and cultural practices can cause damage or wounds are prime infection sites for fungal species increasing the chance for the infection to develop and cause diseases in trees (Slippers and Wingfield, 2007; Abdella, 2004). Conidial dispersal of Botryosphaeria species and initiation of spore release were reported to be correlated with rainfall, fog, dew, overhead irrigation, as water dissolves the mucilage to free the conidia (Gonthier and Nicolotti, 2013). Early spring and summer, late summer and autumn are assumed ideal periods for primary and secondary infections respectively while the former the result of high relative humidity which initiate conidia release and germination (Úrbez-Torres et al., 2016). Increasing temperatures, droughts, floods, range expansions for pests and pathogens and pressure on mutualistic partners are stress aggravating factors on plant communities exposing to serious damaging diseases (Desprez-Loustau et al., 2006; Slippers and Wingfield, 2007). Marsberg et al. (2016), Gonthier and Nicolotti (2013), Slippers and Wingfield (2007) reported that various stresses are causing irreversible or reversible physical damage to tree physiology which enable Botryosphaeria spp., leading causes of diseases which usually manifests affecting both cuticle penetrability and therefore the persistence of the fungi in plant part.

\section{DISEASES AND SYMPTOMS CAUSED BY BOTRYOSPHAERIA ON ECONOMICALLY IMPORTANT TREE SPECIES}

\section{Botryosphaeria dothidea causing diseases of Eucalyptus species}

Botryosphaeria dothidea (Moug. ex Fr) Ces. \& De Not, 1863 , were considered as wound-infecting stress related pathogens and therefore the recent global climate change is predicted to be the main factor for the occurrence of the strain on many plant communities, including trees in the natural woody ecosystems, managed forests and agriculture offering opportunity for a pathogen to infect new hosts (Burgess et al., 2006). The presentwide spread distribution of $B$. dothidea globally has most likely resulted from anthropogenic long-distance dispersal via the worldwide trade of plants and plant products and disease expression is typically attributed to a biotic stress like drought, physical damage, water logging, frost and unsuitable growing environments (Slippers and Wingfield, 2007). Botryosphaeria dothidea is among important quarantine fungi in many countries since it is often easily transported with plant tissues and seeds among countries and regions without showing any visible disease symptoms (Abdella, 2004; Pavlic et al., 2007). The limited host specificity nature of the fungal pathogen enables the fungi to be cross pathogenic once introduced into new area (Marsberg et al., 2016). Botryosphaeria were reported among the pathogens critically influencing Eucalyptus grown in plantations or woodlot causing cankers and dieback followed by production of kino, a dark-red tree sap, and in severe cases mortality of trees (Figure 3) (Denman et al., 2000; Gezahgne et al., 2004; Slippers et al., 2009). These fungi also exist asymptomatically with healthy Eucalyptus leaves, twigs and stems, typically causing disease when there are suitable environmental conditions (Gezahgne et al., 2004; Pérez et al., 2008).
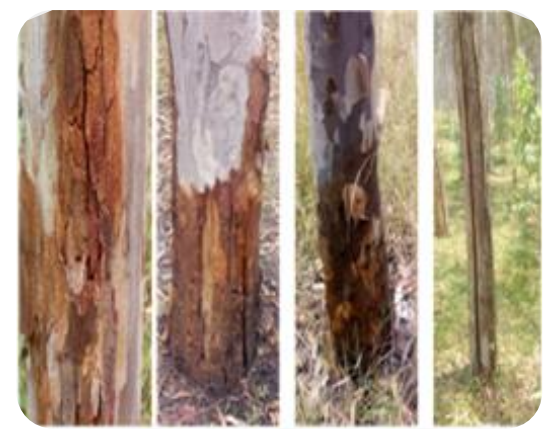

Figure 3. Diseases symptoms associated with Botryosphaeria (Botryosphaeria dothidea) on Eucalyptus grandis plant species (Picture taken from plantation fields, CEE-FRC, 2010).

\section{MANAGEMENT OF TREE DISEASES CAUSED BY BOTRYOSPHAERIA FUNGAL PATHOGENS}

There are no effective fungicide controls for Botryosphaeria diseases, the best management option is to keep plants in optimal health by providing the appropriate cultural management options such as silviculture, avoiding plant stress and injury, and employing appropriate sanitation measures (Slippers and Wingfield, 2007; Úrbez-Torres et al., 2016). Research findings showed that several strategies and their integration can help to effectively manage tree diseases 
caused by Botryosphaeria fungal species.

\section{Plant selection avoidance and exclusion}

Proper plant surveillance for signs of stress during purchase and planting trees at an appropriate landscape can help to minimize Botryosphaeria diseases (Gonthier and Nicolotti, 2013). In commercial forestry speciessite matching, appropriate planting densities and spacing, soil treatment involving fumigation, soil solarization or sanitation to reduce inoculum can be used to minimize exposure of trees to Botryosphaeria diseases (Slippers et al., 2009; Little et al., 2003). Maintenance of soil fertility by addition of fertilizers or compost to avoid nutrient stress, and appropriate irrigation to avoid moisture stress, reducing humidity available for spore release, mycelial growth and infection can minimize host susceptibility and infection (Michailides et al., 2004).

Coating wounds with a fungicidal paint may reduce infection by these and other pathogens (Epstein et al., 2008). Neighboring trees health is also important in nursery settings so that young plants may not get infected by inoculum from surrounding diseased plants (Stanosz et al., 2005).

\section{Resistance}

The use of clonal material with similar genetic features raises likelihood of disease outbreaks in large areas of the world (Pérez et al., 2008). Plant breeding using appropriate screening for resistance and tolerance to species of the Botryosphaeria in forestry and agriculture prior to commercialization and transplanting can be an effective management option against the diseases (Slippers et al., 2009). Research findings of Wingfield et al. (2001) show that breeding for resistance has reduced the impact of diseases such as Cryphonectria stem canker of Eucalyptus spp.to the extent of among the least threatening diseases.

\section{Integrated disease management}

In nurseries, strategies include sanitation, hygiene practices such as the disinfection of grafting shears and pruning tools, wound treatment with a fungicidal paint, pruning at an appropriate time and at a moderate level, and irrigation strategies that minimize exposure to the water or humidity that are available for spore release and mycelial growth can be best approaches to manage diseases due to Botryosphaeria spp. (Epstein et al., 2008;
Cysne et al., 2010; Gonthier and Nicolotti, 2013).

\section{CONCLUSIONS}

$>$ Botryosphaeria fungal spp. evolved from saprophytes to endophytes then to opportunistic pathogens of tree plants.

$>$ Current global climate change is providing an opportunity for Botryosphaeria spp. to cause substantial losses on the plantation tree species in the world.

$>$ Reliable identification of isolates to species level needs advanced molecular technology.

$>$ The infection cycle and epidemiology of Botryosphaeria tree diseases needs further detailed research.

$>$ There is limited information on management of Botryosphaeria tree plantation diseases using fungicides and biocontrol approaches.

$>$ There is little information on mechanism for species overlap and gene flow between native and introduced Eucalyptus and other hosts.

$>$ Botryosphaeria species are well suited to being accidentally moved internationally together with germplasm. The patterns and extent of such movements are not known for most of the species in the world.

\section{REFERENCES}

Abdella, G. 2004. Seed-borne fungi of the afromontane tree species Podocarpus falcatus and Prunus africana in Ethiopia, Swedish University of Agricultural Sciences.

Abdollahzadeh, J., R. Zare and A. J. L. Phillips. 2013. Phylogeny and taxonomy of Botryosphaeria and Neofusicoccum species in Iran, with description of Botryosphaeria scharifii sp. nov. Mycologia, 105: 210-20.

Ahumada, R. 2005. Pathogens in commercial Eucalyptus plantations in Chile, with special reference to Mycosphaerella and Botryosphaeria species, University of Pretoria.

Anderson, P. K., A. A. Cunningham, N. G. Patel, F. J. Morales, P. R. Epstein and P. Daszak. 2004. Emerging infectious diseases of plants: pathogen pollution, climate change and agrotechnology drivers. Trends in Ecology \& Evolution, 19: 535-44.

Burgess, T. I., M. L. Sakalidis and G. E. S. Hardy. 2006. Gene flow of the canker pathogen Botryosphaeria 
australis between Eucalyptus globulus plantations and native eucalypt forests in Western Australia. Austral Ecology, 31: 559-66.

Crous, P. W., B. Slippers, M. J. Wingfield, J. Rheeder, W. F. 0. Marasas, A. J. L. Philips, A. Alves, T. Burgess, P. Barber and J. Z. Groenewald. 2006. Phylogenetic lineages in the Botryosphaeriaceae. Studies in Mycology, 55: 235-53.

Cysne, A. Q., J. E. Cardoso, A. d. H. N. Maia and F. C. Farias. 2010. Spatial-temporal analysis of gummosis in three cashew clones at northeastern Brazil. Journal of Phytopathology, 158: 676-82.

Denman, S., P. W. Crous, J. Z. Groenewald, B. Slippers, B. D. Wingfield and M. J. Wingfield. 2003. Circumscription of Botryosphaeria species associated with proteaceae based on morphology and DNA sequence data. Mycologia, 95: 294.

Denman, S., P. W. Crous, J. E. Taylor, J.-C. Kang, I. Pascoe and M. J. Wingfield. 2000. An overview of the taxonomic history of Botryosphaeria and a reevaluation of its anamorphs based on morphology and ITS rDNA phylogeny. Studies in Mycology, 45: $129-40$.

Desprez-Loustau, M.-L., B. Marçais, L.-M. Nageleisen, D. Piou and A. Vannini. 2006. Interactive effects of drought and pathogens in forest trees. Annals of Forest Science, 63: 597-612.

Epstein, L., K. Sukhwinder and J. S. VanderGheynst. 2008. Botryosphaeria-related dieback and control investigated in noncoastal California grapevines. California Agriculture, 62: 161-66.

Gezahgne, A., J. Roux, B. Slippers and M. J. Wingfield. 2004. Identification of the causal agent of Botryosphaeria stem canker in Ethiopian Eucalyptus plantations. South African Journal of Botany, 70: 241-48.

Gonthier, P. and G. Nicolotti. 2013. Infectious Forest Diseases. CAB International: London, UK.

Jami, F., B. Slippers, M. J. Wingfield and M. Gryzenhout. 2014. Botryosphaeriaceae species overlap on four unrelated, native South African hosts. Fungal Biology, 118: 168-79.

Little, K. M., J. Van Staden and G. P. Y. Clarke. 2003. Eucalyptus grandis $\times$ E. camaldulensis variability and intra-genotypic competition as a function of different vegetation management treatments. New Forests, 25: 227-42.

Mancero-Castillo, D., T. G. Beckman, P. F. Harmon and J. X. Chaparro. 2018. A major locus for resistance to Botryosphaeria dothidea in Prunus. Tree genetics and genomes, 14: 1-10.

Marsberg, A., M. Kemler, F. Jami, J. H. Nagel, A. PostmaSmidt, S. Naidoo, M. J. Wingfield, P. W. Crous, J. W. Spatafora, C. N. Hesse, B. Robbertse and B. Slippers. 2016. Botryosphaeria dothidea: A latent pathogen of global importance to woody plant health. Molecular Plant Pathology, 18: 477-88.

Michailides, T. J., D. P. Morgan and D. Felts. 2004. Collection and characterization of Botryosphaeria dothidea from various hosts and pathogenicity studies on pistachio. KAC Plant Protection Quarterly, 11: 3-8.

Mohali, S. R., B. Slippers and M. J. Wingfield. 2009. Pathogenicity of seven species of the Botryosphaeriaceae onEucalyptusclones in Venezuela. Australasian Plant Pathology, 38: 135.

Moral, J., D. Morgan, A. Trapero and T. J. Michailides. 2019. Ecology and epidemiology of diseases of nut crops and olives caused by Botryosphaeriaceae fungi in California and Spain. Plant Disease, 103: 1809-27.

Pavlic, D., B. Slippers, T. A. Coutinho and M. J. Wingfield. 2007. Botryosphaeriaceae occurring on native Syzygium cordatum in South Africa and their potential threat to Eucalyptus. Plant Pathology, 56: 624-36.

Pérez, C. A., N. Altier, S. Simeto, M. J. Wingfield, B. Slippers and R. A. Blanchette. 2008. Botryosphaeriaceae from eucalyptus and native myrtaceae in Uruguay. Agrociencia, 12: 19-30.

Phillips, A. J. L. 2002. Botryosphaeria species associated with diseases of grapevines in Portugal. Phytopathologia Mediterranea, 41: 3-18.

Phillips, A. J. L. 2016. Special issue on Botryosphaeriaceae. Mycosphere, 7: 868-69.

Phillips, A. J. L., A. Alves, J. Abdollahzadeh, B. Slippers, M. J. Wingfield, J. Z. Groenewald and P. W. Crous. 2013. The Botryosphaeriaceae: Genera and species known from culture. Studies in Mycology, 76: 51167.

Phillips, A. J. L., A. Alves, S. R. Pennycook, P. R. Johnston, A. Ramaley, A. Akulov and P. W. Crous. 2008. Resolving the phylogenetic and taxonomic status of dark-spored teleomorph genera in the Botryosphaeriaceae. Persoonia - Molecular Phylogeny and Evolution of Fungi, 21: 29-55.

Pillay, K., B. Slippers, M. J. Wingfield and M. Gryzenhout. 2013. Diversity and distribution of co-infecting Botryosphaeriaceae from Eucalyptus grandis and Syzygium cordatum in South Africa. South African 
Journal of Botany, 84: 38-43.

Sammonds, J., M. V. Jaspers and E. E. Jones. 2015. Preinfection processes of Botryosphaeriaceae spp: Adhesion of conidia to different substrata. Plant Pathology, 65: 1142-52.

Schoch, C. L., R. A. Shoemaker, K. A. Seifert, S. Hambleton, J. W. Spatafora and P. W. Crous. 2006. A multigene phylogeny of the Dothideomycetes using four nuclear loci. Mycologia, 98: 1041-52.

Slippers, B., E. Boissin, A. J. L. Phillips, J. Z. Groenewald, L. Lombard, M. J. Wingfield, A. Postma, T. Burgess and P. W. Crous. 2013. Phylogenetic lineages in the Botryosphaeriales: A systematic and evolutionary framework. Studies in Mycology, 76: 31-49.

Slippers, B., T. Burgess, D. Pavlic, R. Ahumada, H. Maleme, S. Mohali, C. Rodas and M. J. Wingfield. 2009. A diverse assemblage of Botryosphaeriaceae infectEucalyptusin native and non-native environments. Southern Forests: a Journal of Forest Science, 71: 101-10.

Slippers, B., P. W. Crous, F. Jami, J. Z. Groenewald and M. J. Wingfield. 2017. Diversity in the Botryosphaeriales: Looking back, looking forward. Fungal Biology, 121: 307-21.

Slippers, B., J. Stenlid and M. J. Wingfield. 2005. Emerging pathogens: Fungal host jumps following anthropogenic introduction. Trends in Ecology \& Evolution, 20: 420-21.

Slippers, B. and M. J. Wingfield. 2007. Botryosphaeriaceae as endophytes and latent pathogens of woody plants: diversity, ecology and impact. Fungal
Biology Reviews, 21: 90-106.

Stanosz, G. R., D. R. Smith and J. S. Albers. 2005. Surveys for asymptomatic persistence of Sphaeropsis sapinea on or in stems of red pine seedlings from seven Great Lakes region nurseries. Forest Pathology, 35: 233-44.

Taylor, K., P. A. Barber, G. E. St J. Hardy and T. I. Burgess. 2009. Botryosphaeriaceae from tuart (Eucalyptus gomphocephala) woodland, including descriptions of four new species. Mycological Research, 113: 337-53.

Úrbez-Torres, J. R., F. Castro-Medina, S. R. Mohali and W. D. Gubler. 2016. Botryosphaeriaceae species associated with cankers and dieback symptoms of Acacia mangium and Pinus caribaea var. hondurensis in Venezuela. Plant Disease, 100: 245564.

Vilas-Boas, L. A., M. A. Coronado, G. T. Vilas-Boas, R. F. H. Dekker, A. M. Barbosa and J. E. Garcia. 2007. Determination of a minimal DNA sequence of the internal transcribed spacer region for the in silico Identification of Botryosphaeria sp. Trends in Applied Sciences Research, 2: 201-10.

Wingfield, M. J., J. Roux, T. Coutinho, P. Govender and B. D. Wingfield. 2001. Plantation disease and pest management in the next century. The Southern African Forestry Journal, 190: 67-71.

Yang, T., J. Z. Groenewald, R. Cheewangkoon, F. Jami, J. Abdollahzadeh, L. Lombard and P. W. Crous. 2017. Families, genera, and species of Botryosphaeriales. Fungal Biology, 121: 322-46.

\section{CONFLICT OF INTEREST}

The authors declare that they have no conflicts of interest.

\section{AUTHORS CONTRIBUTIONS}

All the authors contributed equally to this work.

Publisher's note: EScience Press remains neutral with regard to jurisdictional claims in published maps and institutional affiliations.

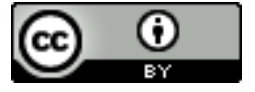

Open Access This article is licensed under a Creative Commons Attribution 4.0 International License, which permits use, sharing, adaptation, distribution and reproduction in any medium or format, as long as you give appropriate credit to the original author(s) and the source, provide a link to the Creative Commons license and indicate if changes were made. The images or other third-party material in this article are included in the article's Creative Commons license, unless indicated otherwise in a credit line to the material. If material is not included in the article's Creative Commons license and your intended use is not permitted by statutory regulation or exceeds the permitted use, you will need to obtain permission directly from the copyright holder. To view a copy of this license, visit http://creativecommons.org/licenses/by/4.0/. 